\title{
Several Vital Relations in Basic Teaching Construction of Transformation Universities
}

\author{
Ming YANG $^{1}$ and Shao-zhi CHEN ${ }^{1}$ \\ ${ }^{1}$ School of Culture and Media, Jilin Engineering Normal College, Changchun, P.R. \\ China
}

Keywords: Transformation, Universities, Teaching construction, Vital relations.

\begin{abstract}
It is imperative to transform local colleges and universities into universities of applied sciences. How to handle following relationships of different universities is vital to the scientific and effective transformation, including major orientation and feature development, teaching mode and practical teaching, structure and type of the teaching body, theoretical teaching and practical teaching and traditional teaching method and heuristic teaching method.

After the Chinese reform and opening up, the higher education in China experienced three stages, including preliminary recovery stage (1978-1998), fast development stage (1999-2009) and stable promotion stage (2011-present), and it has achieved great achievements and process after entering into "mass education" stage through spanning over "elite education "stage, and higher education has provided many important talents and technical support for making China become the second largest economy in the world. In consideration of present scale, China has become a genuine the largest higher education county in the world. However, it is undeniable that there is a great distance between China and the strong higher education country, and there are still many things to do before we meet the requirements of achieving the great Chinese Dream.
\end{abstract}

According to 2011 National Education Development Statistical Bulletin, there are 1,129 universities and 1,280 higher vocational (junior) colleges among the regular institutions for higher learning in 2011, the total enrollment of the regular institutions for higher learning is $6,815,000$, the number of undergraduates is $23,085,100$ and the number of graduates is $6,081,600$. The ration between the number of colleges and universities and the enrollment has basically reached $1: 1$. With such a mass education scale, higher education is no longer the problem of making the masses receive education, but is a significant problem relating to national human resource development and national competitiveness, so it is necessary to recognize and develop our higher education on the height of national human resource optimization and national competitiveness

Under such background, the Standing Committee of the National Council made the decision of "deploy and accelerate modern vocational education" on Feb. 26, 2014. The Ministry of Education hopes to establish a new national modern vocational technical education system by learning from the vocational education system of the developed countries in the world, including Germany, etc. It also hopes to form a integrate new education system consisting of secondary vocational education, higher vocational education, undergraduate vocational education universities of applied sciences), professional master education and professional doctor education through leading the transformation of a group of regular colleges and universities to universities of applied sciences which connects secondary vocational education, higher vocational education. In practice, the first group of 35 regular colleges and universities has joined in the National Universities (Colleges) of Applied Sciences in Jun. 2013 under the direction of the Ministry of Education. It should be known that it is imperative to implement the 
transformation development of local colleges and universities. In April, 2014, 178 colleges and universities in China had published ZHUMADIAN CONSENSUS for promoting the transformation of universities of applied sciences. Lu Xin, Deputy Minister of the Ministry of Education, stresses that the target of education structure adjustment is to solve the structural contradiction of employment, because around $17,000,000$ young people need to find jobs each year. Talents cultivation mode needs to conform to the market need structure, which requires that the lesson, textbook, teaching method, teacher and concept shall all closely focus on the market, so as to solve the contradiction between employment growth and employment inclusiveness.

From the point of education development theory, the development of economy and society demands the higher education to cultivate talents according to "pyramid" structure. In this structure, the talents on the top place are called academic talents, who shall be cultivated by research universities. The high-quality labors in the middle and lower places are called applied talents, who shall be cultivated by local colleges, universities, higher vocational colleges and secondary vocational colleges. The applied talents can also be subdivided into three levels: Technical and skilled talents in basic level, who are mainly cultivated by higher vocational colleges and secondary vocational colleges, creative and applied talents in advanced level, who are mainly cultivated by key national and local universities, and high technical and skilled talents in middle level, who are mainly cultivated by local undergraduate universities which are the universities of applied sciences. This structure determines that the talents cultivation orientation of local undergraduate universities shall differ itself from the "research" and "academic" talents cultivation target made by the traditional academic universities, shall also exceed the "front-line worker" cultivation target for special post made by the higher vocational colleges and secondary vocational colleges and shall lock its target on the cultivation of "engineering" high technical and skilled talents.

At present, the local colleges and universities in China face new dilemmas, which are mainly reflected in the following three aspects: $1^{\text {st }}$ : Severe assimilation in school-running orientation and mode, which makes all colleges and universities look the same and lack features and activities. $2^{\text {nd }}$ : Severe disconnection between academic major and local industrial structure, which results in a low local service capacity. $3^{\text {rd }}$ : The teaching staff prefers education background to capacity, which greatly reduces the professional practical ability of teachers. Therefore, it is necessary to grasp the following relationships in the basic construction of transformation teaching for local colleges and universities: Major orientation and feature development, teaching mode and practical teaching, structure and type of teaching staff, theoretical teaching and practical teaching, traditional teaching method and heuristic teaching method. These relationships play vital roles in the scientific and effective transformation development.

\section{Balance Principle of the Cultivation Orientation of Applied Talents and Research Talents}

In recent years, the school-running mode making all colleges and universities look the same is widely criticized and its core is reflected in the similarity in the professional construction of colleges and universities, which is mainly shown in the following ways: The research universities and applied colleges and universities have little difference in their course setting. The construction of applied universities copies the research universities. Their talents cultivation plans do not show the professional features of different colleges and universities. 
Major orientation shall have its "standards" and shall take the following standards as its basis: $1^{\text {st }}$ : Accordance between major cultivation target and industrial post need. $2^{\text {nd }}$ : Accordance between major course setting and the core capacity and knowledge quality requirements of industrial post. $3^{\text {rd }}$ : Accordance between the teaching effect of major teachers and talents cultivation specification requirements. $4^{\text {th }}$ : Accordance between the teaching patterns and methods of teachers and the reality of students.

The most essential problem in the major construction lies in issue that whether or not the major orientation is accurate. According to the analysis implemented in recent years on the dilemmas of colleges and universities of decline of teaching quality and employment difficulty of graduates, besides the reason of irrational major structure, the blindness and confusion of some colleges and universities shown on their major orientation is also a main root. Due the fast expansion of previous years, many colleges and universities add some majors blindly and open new majors under the premise of having not enough teaching staff and other teaching resources. Due to this reason, some colleges and universities can only copy the professional talents cultivation plans of the early started professional colleges and universities of same type, and they have neglected the argumentation and analysis the supporting degree on the major given in the industrial talents need of local industries, and they do not give due attention and input to the teaching staff condition and lack of other basic conditions in opening relevant majors in their colleges and universities.

The major orientation shall have "feature". The vague major orientation makes many undergraduate universities of applied talents cultivation blindly copy the practices of some research universities without considering the major feature, and the major feature can only be manifested on the basis of confirming an accurate major orientation. The major feature is the "spirits" of the major, the power of major existence and development and one the seeking targets of major construction. Major feature is also an expression of major quality, and the more distinctive the major feature becomes, the higher the major quality becomes. The major feature is expressed in all aspects of major construction, including feature of teaching staff, feature of talents cultivation mode, feature of text system and feature of practical teaching system, etc. Many local colleges and universities shall put more input in the orientation and feature compact of new majors. Only in this way can the passive situation of low training quality of professional talents and feeble employment prospect be tangibly solved.

\section{Appropriate Proportion Principle of Theoretical Teaching Staff and Practical Teaching Staff}

Influenced by the higher education mode thought of Soviet Union in 1950s, the undergraduate education in China still emphasizes on theoretical teaching and the system and integrity of disciplinary knowledge, but neglects practical aspects. Under present situation of higher education popularization, the applied colleges and universities in most places still prefer theory to practice in education conceptions, course system setting and teaching staff arrangement, etc. The undergraduate education of both research universities and applied colleges and universities still have the distinctive problems of neglecting practical teaching, neglecting the construction of practical teaching team, neglecting the input in practical teaching, etc. The problems above can be clearly approved in the following aspects of practical teaching staff in all colleges and universities, including their quantity, titles, education backgrounds, treatments, etc. The number of "double-certificate" teachers in colleges and universities 
is few, the imbalance proportion between practical teachers and theoretical teachers is severe, and the practical teachers are in dispensable status.

In the course system, on one hand, the quantitative proportion of the period of theoretical course is so large that the practical aspect becomes "accessory", and on the other hand, though the proportion of period of practical aspects is increased in recent years, the severe shortage of expense input, practical base and practical teaching staff makes it hard to guarantee the quality of practical teaching and makes it impossible to satisfy the actual talents standard of enterprise posts at all.

\section{Setting Principle of Theoretical Courses System and Practical Courses System}

The relationship between theoretical course and practical course is shown in two aspects: On one hand, it is reflected in quantitative proportion of period is the distinction standard between undergraduate universities and junior colleges, and the on the other hand, it is reflected in content correlation, which means the consistency and mutual support between theory and practical content. The introduction of the theoretical system among the conception, principle, law and function relation of the subject major does not match with the intimacy and adaptation of the policy, technology, management and service mode of relevant industry development.

The purpose of major theoretical course is to master and know the knowledge and capacity points of the basic conception, principle and law of the engaged industry after graduation, and the purpose of major practical course is to solve or adapt the problems and environment of the employment by using the major theoretical knowledge learned in colleges and universities. Therefore, the theoretical course needs to solve the problems of "What" and "Why", and the practical course needs to solve the problems of "How" and "How to do well". For the same major, the relationship between theoretical course and the practical course is "The integration and fusion between learning and doing" and "The purpose of learning is to help doing, and the purpose of doing is to promote learning".

Under the planned economic system and the integrated management mode of elite education school-running orientation and industrial school-running, the cooperation and support of the major practical teaching and the industry guarantees that the quality of major practical teaching will no longer be a problem. Along with the process of alternating the higher education management into national and local second-level management and the fast expansion after the enrollment expansion of colleges and universities, the number of major increases dramatically, and the colleges and universities have separated themselves from the purpose of closely integrating the school-running of industry, business and enterprise. The major teaching of colleges and universities begins to move towards "water injection" development track, and under the dramatic increase of students, the guarantee of practice bases, teachers and special funding has to be achieved at the cost of inevitable deterioration of the teaching quality, which will cause the worrying employment difficulties of undergraduates to the government, college, university and society.

In recent years, there are some successful cases on the exploration and practice results of the government-industry-university-institute collaboration. However, we can find some common features of the so-called successful cooperation in running school through careful analysis, and the main feature is that the cooperative colleges and universities are all high level universities which own stronger scientific research strength and talents endowment to provide technical support to enterprises. However, for the local colleges and universities with low social service capacity and separation 
from industrial management, they deceive themselves and others in solving the major practice problem of their students. The so-called score type internship is now in difficulties, and the reasons are that the enterprise has not responsibility, obligation and capacity to bear the practice mission of the colleges and universities, and many enterprises do not rely on the employment market of colleges and universities, because the experienced technical and management personnel in the industry is easier to satisfy the enterprise target of "come and work". The colleges and universities have no capacity to build a practice base conforming to the technical level of enterprise, which cuts off the connection between the major construction of colleges and universities and enterprise and causes the result of close-door school-running.

In a long time, neither can this problem be solved by colleges, universities and enterprises, nor can it be solved by the input into education from enterprise. The only tangible method is to make the local government know the problem and find solution through long consideration. The method is to introduce relevant policies through local legislation which combine the practice mission of major education of local colleges and universities with the responsibilities and obligations of local enterprises, and solve the problem gradually through implementing the methods of force planned share, tax reduction, activation through reward, etc. and through establishing a practice management platform by the education department. Moreover, the local colleges and universities shall promote their school-running features, provide technical service and high quality talents and tangibly make themselves become strong in their major construction, so the colleges and universities will have enough power to serve the enterprises and industries and the enterprises will also actively seek the cooperation with local colleges and universities.

\section{Relationship between Traditional Teaching Method and New Teaching Method}

The core of major construction of colleges and universities is to cultivate the necessary professional talents for some industries, especially the construction of engineering technology major or applied major with direction relationship with the industrial enterprises, so they shall keep a close contact with the enterprises in the industry and business they are serving, or the construction of the relevant major will separate itself from reality. Now the major construction in many colleges and universities are facing such a problem.

Theoretically, the colleges and universities shall own enough guarantee in teaching staff and enough practice site for arranging practice equipments. If the conditions above are achieved, the colleges and universities can fully meet the target requirements independently under the premise of guaranteeing the due teaching arrangement, but in fact, the teaching staff for the applied major and the support of teaching resource condition in most of the colleges and universities, especially local colleges and universities, are far from the standard requirements for cultivating the urgent needed talents for some industrial enterprises. Therefore, how to keep the close connection between the industry and colleges and universities is an urgent and practical problem, which needs to be solved theoretically.

The starting point of colleges and universities is to enroll students and enlarge their scales, which needs both large amount of input, talents cultivation resource and enterprise support, and the cooperation between enterprises, colleges and universities is to provide support to professional talents and the technology of colleges and universities. The condition for the cooperation is that the cooperation can benefit the enterprises, colleges and universities. If the major opened by colleges and universities 
can only enroll students, but cannot provide guarantee in teacher reserve, technical service and practice condition, the cooperative enterprises cannot get technical support and talents supplement, and they will not solve their difficulties by cooperating with colleges and universities. This is meaningless for the colleges and universities which open the major.

At present, there are three method options for applied major construction: $1^{\text {st }}$ : The colleges and universities fully own the necessary practice conditions for opening new major and connecting actual demand. Under such a condition, the colleges and universities can implement their major construction without seeking cooperation with enterprises. $2^{\text {nd }}$ : The colleges and universities own the capacity of providing the applied talents for enterprises and providing technology and R\&D cooperation to meet the need of enterprise. $3^{\text {rd }}$ : The colleges and universities lack the conditions for opening a major for the time being and lack the external cooperative conditions with enterprises, so they can only rely on gradually building their own teaching staff group and teaching practice conditions. At present the $3^{\text {rd }}$ situation takes up a large proportion, and the cost of it is to sacrifice the quality of teaching quality, or the major has to be stopped.

Under present independent school-running system of undergraduate universities, the first situation above is the advanced stage of the second situation. For the third situation, the relevant colleges and universities shall pay attention to increase the input in building a teaching staff group for the construction of new major, especially the introduction and cultivation of leader and the external enterprise training of "double-certificate" teachers. They shall also send their major teachers to take further education and training in national and foreign key universities as soon as possible. They shall also construct the practice base and purchase teaching instruments and equipments for the major, which can guarantee the need of technical capacity cultivation of basic major practice software and hardware.

\section{Acknowledgement}

This paper was financially supported by from the National Social Science Fund Project for Young Scholars (No. 14CXW041), and the projects in the Educational Science Plan of Jilin Province in 2014 (No. GH14430) and the Social science research project of Jilin Province Education Department in2015 (No.303).

\section{References}

[1] Chen Jie, Huang Wenwei. Exploration on Professional Talents Cultivation of Port and Shipping Major in the Transformation Period of Colleges and Universities. [J].College Education,2014(2):64-66

[2] Zhu Jionglin, Zhang Lin, Fang Zhufang. Exploration and Analysis on the Cultivation Optimization Strategies of Young Teachers under Transformation Drive of Colleges and Universities. [J].Journal of Zhejiang University of Technology, 2014(3):71-74.

[3] Jia Meiyan. Reconstruction of Teachers' Self-identity under the Transformation Development Background of Local Colleges and Universities. [J].Adults Education in China, 2014(3):106-108.

[4] Meng Qingguo, Cao Ye. Transformation Development of Local Colleges and Universities: Method Selection and Connotation Construction [J]. Vocational and Technical Education, 2014(6):68-71. 
[5] Li Luping, Cao Jun, Zhang Yonghua. Method Exploration of Talents Cultivation Transformation in the Transformation Process of Universities. [J].Modern Education Forum (Management),2010(1).

[6] Zhu Shizhon. On the Transformation Development of Applied Teaching Staff Group in Undergraduate Universities [J]. Modern Education Science, 2010(9).

[7] Transformation of Common Colleges and Universities, How to Greet the Time of Applied Universities? [EB/OL].

http://www.js-edu.cn/Html/201404/28/20140428095654.htm. 2014-4-28 